\title{
Effect of applying standards for labor and delivery nursing care on performance of nurses
}

\author{
Naglaa Fathy Ahmed*, Shadia Hamido Mohasib**, Ekbal Abd El Rehem Emam***
}

* Assistant lecturer of maternity and obstetric health nursing Faculty of Nursing -Minia University
** Professor of maternity and gynecology health nursing Faculty of Nursing - Ain shams University
*** Assistant Professor of maternity and obstetric health nursing Faculty of Nursing -Minia University

\section{Abstract}

Background Childbirth is one of the most important events in the life of a woman however, the care provided and practices for childbirth are not standardized. The aim of this study was to evaluate the Effect of applying standards for labor and delivery nursing care on performance of nurses. A quasi- experimental design was adopted. The study was carried out at labor and delivery units in Minia hospitals (Obstetric University Hospital, General hospital and Health Insurance at Labor unit) .Convenience sample for all (50 nurses) who were working in different labor and delivery units during the study in the previous settings. Tools, An interviewing questionnaire for nurses was developed by the researcher and the second was performance standards for maternal and neonatal health Normal Labor and Delivery (NLD) .Results The significant difference were found concerning, immediately and after 3 months and total scores of nurses' performance were highly statistical significant difference was illustrated ( $p$ $<0.001)$, while the mean scores of nurses' performance $(163.5 \pm 8.2)$ immediate post test was the higher than 3 months later after application of standards (138.9 \pm 11.5$)$, and pretest (107.1 \pm 3.1$)$, Conclusion: there was improvement in achievements of performance standards for maternal and neonatal health: Normal Labor and Delivery (NLD) after application of this study immediately better than three months later follow up . Recommendation: Develop evidence-based maternity \& neonatal care manual in all hospital based on established evidence-based practice with national standards. Nursing performance appraisal to ensure that nursing care level in maternal \&neonatal units follow standardized care manuals.

Key wards: applying Standards, labor and delivery, nursing care, performance of nurses

\section{Introduction:}

Every year, more than 200 million women become pregnant. Most pregnancies end with The birth of a live baby to a healthy mother. childbirth is not the joyous event; it is a time of pain, fear, suffering and even death. Because of difficulties associated with human birth, women often require assistance during delivery. Childbirth may be surrounded by traditions, many of which are beneficial, but others may be harmful (1).

Childbirth is a risky event for babies too. The complications that cause the deaths and disabilities for mothers also damage the infants they are carrying. These perinatal and neonatal deaths are largely the result of the same factors that cause the deaths and disabilities for mothers (2). Childbirth is a normal physiological process and as such should not be life threatening to the women who experience it. However, in developing countries where pregnancy is complicated by the harsh realities of malnutrition, poverty and the disease associated with them, giving birth dire consequences for mother and child. As a result of child birth, half a million women worldwide die annually (3).

Standardized care is required in health facilities, to address the problems of maternal and neonatal health in developing countries, to define the level of performance, improve the quality of services provided and ultimately reduce maternal and neonatal deaths. Only a few reports exist on hospital adherence to these standards. Such information is useful because it identifies critical functions that are not performed and could inform quality improvement efforts $(4,5)$.

Healthy mother and a healthy baby and family integrity must be the focus of high quality maternity services. High quality care should be safe, effective, woman-centered, timely and equitable. It should also be evidence-based and delivered as close as possible to the communities where women live or work. It should continue to be free and accessible to everyone at the point of need (6, 7).

All women need nursing care at every stage of labor. The nurse or midwife helps women make decisions based on their clinical need, values and preferences, on the research evidence and on the context of care (8).

\section{Aim of the Study}

The current study was carried out to evaluate the Effect of applying standards for labor and delivery nursing care on performance of nurses.

\section{Research Hypothesis}

There will be a positive effect of Applying Standards for nursing care on nursing performance at the labor unit.

\section{Subjects and Methods Research design:}

The Quasi- experimental design (pre and post test) was adopted in the current study to reach the stated aim.

\section{Study setting:}

The present study was conducted in Minia hospitals ( Obstetric University Hospital, General hospital and Health Insurance at the Labor unit). Obstetric university hospital divided into three floors: first floor containing 2 rooms (gynecology and antenatal care clinics). Second floor containing (15) rooms for gynecological diseases and postoperative care and third floor containing (15) rooms of (obstetric ward) and section contains delivery room, and operating room. 
El-Minia general hospital divided into three floors; first floor containing 2 rooms gynecology and family planning clinics and one operating room, Second floor containing ( infection control unit), and Third floor containing one room for delivery and one room for postoperative care.

Health Insurance at Labor unit divided into seven floors: third floor containing 3 rooms (antenatal care and post natal ) and two delivery room

\section{Sample}

Convenience sample of 50 nurses who were working in different labor and delivery units during the study in the previous settings

\section{Inclusion criteria}

Each nurse works in labor and delivery unit (which includes settings for normal delivery and provide immediate care of the newborn.

\section{Exclusion criteria.}

Any nurse works in OB-GYN department at Maternity unit but not participating neither in delivery unit work nor providing immediate care of the Newborn was excluded.

\section{Tools of data collection}

To achieve the purpose of current study, data has been collected by using the following two tools:

(Tool one): Interviewing questionnaire sheet: This questionnaire was developed, translated and utilized by the researcher to collect the necessary data to be filled by nurses who were involved in the provision of direct care in labor unit, such as (Age, level of education, years of experience in labor unit, and previous attended nursing training about care during labor. knowledge related to first, second, third and fourth stage of labor.

(Tool two): The performance standards for maternal and neonatal Health. This tool was prepared by Johns Hopkins Program for International Education in Gynecology and Obstetrics (JHPIEGO, 2011), to assess the actual performance of health care providers caring for women in labor and delivery units it included 9 performance standards. Normal Labor and Delivery (NLD)

NLD-01 standard, which is related to "The provider properly in charge prepare equipments, supplies and the environment to conduct clean and safe deliveries this included 6 criteria, NLD-03 standard, which is related to "The provider treatment the pregnant woman in labor in a cordial manner" this contains 9 criteria, NLD-06 standard, which is related to "The provider properly conducts the obstetric examination between contractions if time allows" it included 9 criteria, NLD-7 standard, which is related to "The provider properly conducts a vaginal examination" including 11 criteria, NLD-11 standard, which is related to "The healthcare provider informs or reinforces information about infant feeding-emphasizing Breastfeeding" including 6 criteria, NLD-13 standard, which is related to "The provider uses the partograph to monitor labor and makes adjustments to care when necessary" including 16 criteria, NLD- 14 standard, which is related to provider prepares to assist the delivery/ birth, it included 9 criteria, NLD-17 standard, which is related to "The provider properly monitors the newborn and provides essential initial newborn care and subsequent care" including 10 criteria and NLD-18 standard, which is related to "The provider properly disposes of the used instruments and medical waste after assisting the birth including 7 criteria.

\section{Ethical considerations:}

Each participant nurse in the study was informed that her rights would be secured, informed about the nature, process, and expected outcomes of the study, reassured that the study procedures would be harmless, reassured that all data would be confidential and would be used only for the research purposes, and informed about her rights to withdraw at any time throughout the study.

\section{Statistical Design:}

The collected data were organized, tabulated and analyzed using statistical package of social science (SPSS) 19.0 programs

\section{Results}

Table (1) Distribution of the study sample according to their age, Marital status and level of education (n=50)

\begin{tabular}{|l|l|l|}
\hline Items & no $=50$ & $\%$ \\
\hline Age of nurses': & 10 & 20.0 \\
Less than 20 years & 32 & 64.0 \\
From 20 to 30 years & 8 & 16.0 \\
30 years and more & & \\
Mean \pm SD & 19 & 38.0 \\
\hline Years of experience: & 15 & 30.0 \\
Less than 5 years & 16 & 32.0 \\
From 5 to 10 years & 18 & 36.0 \\
10 years and more & 32 & 64.0 \\
\hline Birth Training courses & & \\
Yes & 8 & 16.0 \\
No & 11 & 22.0 \\
\hline Qualification of nurses': & & \\
Bachelor of sciences in nursing & & \\
Technical institute of nursing & & \\
\hline
\end{tabular}




\begin{tabular}{|c|l|l|}
\hline Items & no= $=50$ & $\%$ \\
\hline Secondary nursing diploma & 31 & 62.0 \\
\hline
\end{tabular}

Table (1) shows the distribution of nurses according to their socio-demographic characteristics. It was found that the age of more than half of the nurses $(64.0 \%)$ ranged from 20 to less than 30 years. As regards their qualification more than half of the nurses $(62.0 \%)$ hade secondary nursing Diploma education while nurses who had a Bachelor of Science in nursing were $(16.0 \%)$ the majority of nurses $(38 \%)$ were relatively new in the career and had work experience less than 5 years.. As Regards to birth training courses, $(64.0 \%)$ of nurses didn't attend birth training courses and (36.0\%) of nurses' had attended birth training courses.

\section{Table (2) Distribution of Nurses' performance regarding NLD-01 standard}

\begin{tabular}{|c|c|c|c|c|c|c|c|c|}
\hline \multirow{2}{*}{$\begin{array}{l}\text { The provider in charge prepares equipment, } \\
\text { supplies and the environment to conduct clean and } \\
\text { safe deliveries }\end{array}$} & \multicolumn{2}{|c|}{$\begin{array}{l}\text { Pre } \\
\mathrm{N}=50\end{array}$} & \multicolumn{2}{|c|}{$\begin{array}{l}\text { Immediate } \\
\mathrm{N}=50\end{array}$} & \multicolumn{2}{|c|}{$\begin{array}{l}\text { After } 3 \text { months } \\
\mathrm{N}=50\end{array}$} & \multirow[t]{2}{*}{$\chi^{2}$} & \multirow[t]{2}{*}{ P-value } \\
\hline & Freq. & $\%$ & Freq & $\%$ & Freq & $\%$ & & \\
\hline Ensures that the delivery room is clean. & 24 & 48.0 & 50 & 100 & 50 & 100 & 62.903 & $.000^{*}$ \\
\hline $\begin{array}{l}\text { Ensures that the supplies and equipment to perform } \\
\text { normal deliveries are available. }\end{array}$ & 50 & 100 & 50 & 100 & 50 & 100 & $\ldots$ & $\ldots$ \\
\hline $\begin{array}{l}\text { Ensures that the supplies and equipment to manage } \\
\text { the normal newborn including appropriate room } \\
\text { temperature are available. }\end{array}$ & 50 & 100 & 50 & 100 & 50 & 100 & $\ldots$ & $\ldots$ \\
\hline $\begin{array}{l}\text { Ensures that the supplies and equipment to manage } \\
\text { any maternal or newborn complication are available. }\end{array}$ & 50 & 100 & 50 & 100 & 50 & 100 & $\cdots \cdots$ & $\cdots$ \\
\hline $\begin{array}{l}\text { Ensures that the supplies and materials for infection } \\
\text { prevention are available. }\end{array}$ & 15 & 30.0 & 50 & 100 & 29 & 58.0 & 53.059 & $.000^{*}$ \\
\hline $\begin{array}{l}\text { Ensures that the clerking notes, partograph, and all } \\
\text { necessary registers are available. }\end{array}$ & 0 & .0 & 50 & 100 & 0 & .0 & 150.00 & $.000 *$ \\
\hline
\end{tabular}

Statistically significant difference

Table (2) shows that, there were no statistically significant differences in nurses performance score regarding NLD-01 standard (The provider in charge prepares equipment, supplies and the environment to conduct clean and safe deliveries) (Ensures that the supplies and equipment to perform normal deliveries, Ensures that the supplies and equipment to manage the normal newborn and Ensures that the supplies and equipment to manage any maternal or newborn complications), at base line assessment
( $\mathrm{p}>0.05)$. While the difference observed was highly statistically significant improvement in total performance score of nurses regarding (Ensures that the supplies and materials for infection prevention are available. And Ensures that the clerking notes, partograph, and all necessary registers are available) immediately higher than three months of intervention compared with base line total score $(\mathrm{P}<0.001)$.

\section{Table (3) Distribution of Nurses' performance regarding NLD-03 standard}

\begin{tabular}{|c|c|c|c|c|c|c|c|c|}
\hline \multirow{2}{*}{$\begin{array}{l}\text { The provider treats the pregnant woman in labor in a } \\
\text { cordial manner. }\end{array}$} & \multicolumn{2}{|l|}{$\begin{array}{l}\text { Pre } \\
\mathrm{N}=50\end{array}$} & \multicolumn{2}{|c|}{$\begin{array}{l}\text { Immediate } \\
\mathrm{N}=50\end{array}$} & \multicolumn{2}{|c|}{$\begin{array}{l}\text { After } 3 \text { months } \\
\mathrm{N}=50\end{array}$} & \multirow[t]{2}{*}{$\chi^{2}$} & \multirow[t]{2}{*}{ P-value } \\
\hline & Freq. & $\%$ & Freq. & $\%$ & Freq. & $\%$ & & \\
\hline $\begin{array}{l}\text { Greets the woman and her husband or companion in a } \\
\text { cordial manner }\end{array}$ & 50 & 100 & 50 & 100 & 50 & 100 & ... & ..... \\
\hline Introduces her/himself & 0 & .0 & 50 & 100 & 50 & 100 & 150.00 & $.000^{*}$ \\
\hline Explains care before any examination or procedures & 0 & .0 & 50 & 100 & 50 & 100 & 150.00 & $.000 *$ \\
\hline $\begin{array}{l}\text { Discreetly asks woman if she would like someone to } \\
\text { remain with her during the examination, labor and } \\
\text { delivery }\end{array}$ & 0 & .0 & 0 & .0 & 0 & .0 & $\cdots \cdot$ & $\cdots \cdots$ \\
\hline Responds to questions using easy-to-understand & 12 & 24.0 & 50 & 100 & 50 & 100 & 101.786 & $.000 *$ \\
\hline
\end{tabular}


Minia Scientific Nursing Journal (Print) (ISSN 2537-012X) Vol. (3) No. (1) July 2018

\begin{tabular}{|c|c|c|c|c|c|c|c|c|}
\hline \multirow[t]{2}{*}{$\begin{array}{l}\text { The provider treats the pregnant woman in labor in a } \\
\text { cordial manner. }\end{array}$} & \multicolumn{2}{|c|}{$\begin{array}{l}\text { Pre } \\
\mathrm{N}=50\end{array}$} & \multicolumn{2}{|c|}{$\begin{array}{l}\text { Immediate } \\
\mathrm{N}=50\end{array}$} & \multicolumn{2}{|c|}{$\begin{array}{l}\text { After } 3 \text { months } \\
\mathrm{N}=50\end{array}$} & \multirow[t]{2}{*}{$\chi^{2}$} & \multirow[t]{2}{*}{ P-value } \\
\hline & Freq. & $\%$ & Freq. & $\%$ & Freq. & $\%$ & & \\
\hline $\begin{array}{l}\text { Responds to her immediate needs (thirst, hunger, } \\
\text { cold/hot, need to urinate, etc.) }\end{array}$ & 50 & 100 & 50 & 100 & 50 & 100 & $\ldots \ldots$ & $\ldots$ \\
\hline
\end{tabular}

* Statistically significant difference

Table (3) explore that, there were highly statistically significant improvement in total performance score of nurses regarding NLD-03 standard (The provider treats the pregnant woman in labor in a cordial manner) in this criteria (Introduces her/himself, Explains care before any examination or procedures and Responds to questions using easy-to-understand language) (Pre, post and 3 months later after application of standards $)(\mathrm{p}<0.001)$

Table (4) Distribution of Nurses' performance regarding NLD-06 standard

\begin{tabular}{|c|c|c|c|c|c|c|c|c|}
\hline \multirow{2}{*}{$\begin{array}{l}\text { NLD-06 } \\
\text { The provider properly conducts the obstetric } \\
\text { examination between contractions if time allows. }\end{array}$} & \multicolumn{2}{|l|}{$\begin{array}{l}\text { Pre } \\
\mathrm{N}=50\end{array}$} & \multicolumn{2}{|c|}{$\begin{array}{l}\text { Immediate } \\
\mathrm{N}=50\end{array}$} & \multicolumn{2}{|c|}{$\begin{array}{l}\text { After } 3 \text { months } \\
\mathrm{N}=50\end{array}$} & \multirow[t]{2}{*}{$\chi^{2}$} & \multirow[t]{2}{*}{ P-value } \\
\hline & Freq. & $\%$ & Freq. & $\%$ & Freq. & $\%$ & & \\
\hline $\begin{array}{l}\text { Observes the shape and size of the abdomen and } \\
\text { checks for the presence of scars and other skin } \\
\text { lesions }\end{array}$ & 15 & 30.0 & 35 & 70.0 & 29 & 58.0 & 17.477 & $.000 *$ \\
\hline Avoids examining the woman during a contraction & 0 & .0 & 15 & 30.0 & 17 & 34.0 & 20.577 & $.000^{*}$ \\
\hline Measures fundal height & 0 & .0 & 15 & 30.0 & 17 & 34.0 & 20.577 & $.000^{*}$ \\
\hline $\begin{array}{l}\text { Determines presentation, fetal lie and degree of } \\
\text { engagement by abdominal palpation }\end{array}$ & 2 & 4.0 & 29 & 58.0 & 27 & 54.0 & 38.175 & $.000 *$ \\
\hline $\begin{array}{l}\text { Evaluates and grades uterine contractions } \\
\text { (frequency and duration over a } 10 \text { minute period) }\end{array}$ & 0 & .0 & 15 & 30.0 & 17 & 34.0 & 20.577 & $.000^{*}$ \\
\hline $\begin{array}{l}\text { Asks if the baby is moving regularly and observes } \\
\text { for fetal movement during the examination }\end{array}$ & 2 & 4.0 & 29 & 58.0 & 27 & 54.0 & 38.175 & $.000^{*}$ \\
\hline $\begin{array}{l}\text { Auscultates fetal heart rate (FHR) over a } 10 \\
\text { minute period (fetal heart rate and changes before, } \\
\text { during, and after a contraction) }\end{array}$ & 2 & 4.0 & 29 & 58.0 & 27 & 54.0 & 38.175 & $.000^{*}$ \\
\hline Records the results of the obstetric examination on & 2 & 4.0 & 29 & 58.0 & 27 & 54.0 & 38.175 & $.000^{*}$ \\
\hline $\begin{array}{l}\text { Explains her findings to the woman and her } \\
\text { husband/companion }\end{array}$ & 0 & .0 & 15 & 30.0 & 17 & 34.0 & 20.577 & $.000 *$ \\
\hline
\end{tabular}

* Statistically significant difference

Table (4) explore that, there were statistically significant improvement in total performance score of nurses regarding NLD-06 standard (The provider properly conducts the obstetric examination between contractions if time allows) immediately and 3 months later after application of standards) $(\mathrm{p}<0.001)$

Table (5) Distribution of Nurses' performance regarding NLD-7 standard

\begin{tabular}{|c|c|c|c|c|c|c|c|c|}
\hline \multirow{2}{*}{$\begin{array}{l}\text { Stand } 7 \\
\text { The provider properly conducts a vaginal } \\
\text { examination. }\end{array}$} & \multicolumn{2}{|c|}{$\begin{array}{l}\text { Pre } \\
\mathrm{N}=50\end{array}$} & \multicolumn{2}{|c|}{$\begin{array}{l}\text { Immediate } \\
\mathrm{N}=50\end{array}$} & \multicolumn{2}{|c|}{$\begin{array}{l}\text { After 3months } \\
\mathrm{N}=50\end{array}$} & \multirow[t]{2}{*}{$\chi^{2}$} & \multirow[t]{2}{*}{ P-value } \\
\hline & Freq. & $\%$ & Freq. & $\%$ & Freq. & $\%$ & & \\
\hline $\begin{array}{l}\text { 1-Explains to the woman in easy-to-understand } \\
\text { language what she is going to do }\end{array}$ & 49 & 98.0 & 50 & 100.0 & 17 & 34.0 & 80.401 & $.000^{*}$ \\
\hline 2-Performs hand hygiene after removing gloves & 0 & .0 & 50 & 100.0 & 17 & 34.0 & 104.603 & $.000^{*}$ \\
\hline $\begin{array}{l}\text { 3-Puts on surgical sterile or high-level disinfected } \\
\text { (HLD) gloves on both hands }\end{array}$ & 0 & .0 & 49 & 98.0 & 17 & 34.0 & 100.487 & $.000^{*}$ \\
\hline $\begin{array}{l}\text { 4-Examines the vulva (ulcers, blood, liquid, } \\
\text { secretion) }\end{array}$ & 23 & 46.0 & 50 & 100.0 & 17 & 34.0 & 51.500 & $.000 *$ \\
\hline 5-Cleans the vulva with an antiseptic & 0 & .0 & 50 & 100.0 & 17 & 34.0 & 104.603 & $.000 *$ \\
\hline $\begin{array}{l}\text { 6-If the membranes are ruptured, then conducts a } \\
\text { vaginal cleansing with chlorhexidine prior to } \\
\text { vaginal examinations }\end{array}$ & 21 & 42.0 & 50 & 100.0 & 17 & 34.0 & 53.501 & $.000^{*}$ \\
\hline
\end{tabular}


Minia Scientific Nursing Journal (Print) (ISSN 2537-012X) Vol. (3) No. (1) July 2018

\begin{tabular}{|c|c|c|c|c|c|c|c|c|}
\hline \multirow{2}{*}{$\begin{array}{l}\text { Stand } 7 \\
\text { The provider properly conducts a vaginal } \\
\text { examination. }\end{array}$} & \multicolumn{2}{|c|}{$\begin{array}{l}\text { Pre } \\
\mathrm{N}=50\end{array}$} & \multicolumn{2}{|c|}{$\begin{array}{l}\text { Immediate } \\
\mathrm{N}=50\end{array}$} & \multicolumn{2}{|c|}{$\begin{array}{l}\text { After 3months } \\
\mathrm{N}=50\end{array}$} & \multirow[t]{2}{*}{$\chi^{2}$} & \multirow[t]{2}{*}{ P-value } \\
\hline & Freq. & $\%$ & Freq. & $\%$ & Freq. & $\%$ & & \\
\hline $\begin{array}{l}\text { 7-Assesses cervical dilatation, molding, and level } \\
\text { of presenting part, Caput, State of the MRS, if } \\
\text { ruptured the color of liquor }\end{array}$ & 21 & 42.0 & 50 & 100.0 & 17 & 34.0 & 53.501 & $.000 *$ \\
\hline 8-Properly disposes of gloves & 20 & 40.0 & 50 & 100.0 & 17 & 34.0 & 104.603 & $.000 *$ \\
\hline 9- Performs hand hygiene after removing gloves & 0 & .0 & 50 & 100.0 & 17 & 34.0 & 104.603 & $.000^{*}$ \\
\hline $\begin{array}{l}\text { 10-Explains to the woman the findings and what } \\
\text { they mean. }\end{array}$ & 0 & .0 & 50 & 100.0 & 17 & 34.0 & 104.603 & $.000 *$ \\
\hline 11-Registers findings & 0 & .0 & 50 & 100.0 & 17 & 34.0 & 104.603 & $.000^{*}$ \\
\hline
\end{tabular}

* Statistically significant difference

Table (5) show that, there were highly statistically significant improvement in total performance score of nurses regarding NLD-7 standard (The provider properly conducts a vaginal examination) immediately better than after three months of intervention compared with base line total score $(\mathrm{P}<0.001)$.

Table (6) Distribution of Nurses' performance regarding NLD-13 standard

\begin{tabular}{|c|c|c|c|c|c|c|c|c|}
\hline \multirow{2}{*}{$\begin{array}{l}\text { NLD-13 } \\
\text { The provider uses the partograph to monitor labor } \\
\text { and make adjustments to care when necessary }\end{array}$} & \multicolumn{2}{|l|}{$\begin{array}{l}\text { Pre } \\
\mathrm{N}=50\end{array}$} & \multicolumn{2}{|c|}{$\begin{array}{l}\text { Immediate } \\
\mathrm{N}=50\end{array}$} & \multicolumn{2}{|c|}{$\begin{array}{l}\text { After } 3 \text { months } \\
\mathrm{N}=50\end{array}$} & \multirow[t]{2}{*}{$\chi^{2}$} & \multirow[t]{2}{*}{ P-value } \\
\hline & Freq. & $\%$ & Freq. & $\%$ & Freq. & $\%$ & & \\
\hline Records patient information on a partograph. & 0 & .0 & 50 & 100 & 14 & 28.0 & 108.794 & $.000 *$ \\
\hline $\begin{array}{l}\text { Evaluates fetal heart rate, maternal pulse, and } \\
\text { frequency/duration of contractions in a } 10 \text {-minute } \\
\text { period every half hour }\end{array}$ & 0 & .0 & 50 & 100 & 14 & 28.0 & 108.794 & $.000^{*}$ \\
\hline $\begin{array}{l}\text { If membranes are ruptured, evaluates color and } \\
\text { odor of liquor every half hour }\end{array}$ & 0 & .0 & 50 & 100 & 14 & 28.0 & 108.794 & $.000 *$ \\
\hline Evaluates blood pressure every two & 0 & .0 & 50 & 100 & 14 & 28.0 & 108.794 & $.000 *$ \\
\hline Evaluates temperature every four hours & 0 & .0 & 50 & 100 & 14 & 28.0 & 108.794 & $.000^{*}$ \\
\hline $\begin{array}{l}\text { Evaluates cervical dilatation and fetal descent } \\
\text { every four hours }\end{array}$ & 0 & .0 & 50 & 100 & 14 & 28.0 & 108.794 & $.000^{*}$ \\
\hline $\begin{array}{l}\text { Performs hands hygiene before and after every } \\
\text { vaginal examination }\end{array}$ & 0 & .0 & 50 & 100 & 14 & 28.0 & 108.794 & $.000^{*}$ \\
\hline $\begin{array}{l}\text { If the membranes are ruptured, then conducts a } \\
\text { vaginal cleansing with chlorhexidine prior to } \\
\text { vaginal examinations }\end{array}$ & 0 & .0 & 50 & 100 & 14 & 28.0 & 108.794 & $.000^{*}$ \\
\hline $\begin{array}{l}\text { Wears sterile gloves for each vaginal examination } \\
\text { and disposes them properly }\end{array}$ & 0 & .0 & 50 & 100 & 14 & 28.0 & 108.794 & $.000 *$ \\
\hline $\begin{array}{l}\text { Records required partograph information after } \\
\text { every evaluation).. }\end{array}$ & 0 & .0 & 50 & 100 & 14 & 28.0 & 108.794 & $.000^{*}$ \\
\hline $\begin{array}{l}\text { If membranes rupture, record time of rupture and } \\
\text { color / character of liquor }\end{array}$ & 0 & .0 & 50 & 100 & 14 & 28.0 & 108.794 & $.000^{*}$ \\
\hline $\begin{array}{l}\text { Records the amount of urine output each time the } \\
\text { woman empties the bladder }\end{array}$ & 0 & .0 & 50 & 100 & 14 & 28.0 & 108.794 & $.000^{*}$ \\
\hline $\begin{array}{l}\text { Records protein and acetone in urine each time } \\
\text { they are tested }\end{array}$ & 0 & .0 & 50 & 100 & 14 & 28.0 & 108.794 & $.000^{*}$ \\
\hline $\begin{array}{l}\text { Records IV fluids and medications administered } \\
\text { immediately after they are given }\end{array}$ & 0 & .0 & 50 & 100 & 14 & 28.0 & 108.794 & $.000^{*}$ \\
\hline Records the time of the above observations & 0 & .0 & 50 & 100 & 14 & 28.0 & 108.794 & $.000^{*}$ \\
\hline $\begin{array}{l}\text { Adjusts care according to the parameters } \\
\text { encountered: }\end{array}$ & 0 & .0 & 50 & 100 & 14 & 28.0 & 108.794 & $.000 *$ \\
\hline
\end{tabular}

Statistically significant difference

Table (6) explore that, there were highly statistically significant improvement in total performance score of nurses regarding NLD-13 standard (The provider uses the partograph to monitor labor and make adjustments 
Minia Scientific Nursing Journal (Print) (ISSN 2537-012X) Vol. (3) No. (1) July 2018

to care when necessary) immediately higher than with base line improvement after three months of intervention compared

$0.001)$

Table (7) Distribution of Nurses' performance regarding NLD-14 standard

\begin{tabular}{|c|c|c|c|c|c|c|c|c|}
\hline \multirow[t]{2}{*}{$\begin{array}{l}\text { NLD-14 } \\
\text { The provider prepares to assist the delivery/ birth. }\end{array}$} & \multicolumn{2}{|l|}{$\begin{array}{l}\text { Pre } \\
\mathrm{N}=50\end{array}$} & \multicolumn{2}{|c|}{$\begin{array}{l}\text { Immediate } \\
\mathrm{N}=50\end{array}$} & \multicolumn{2}{|c|}{$\begin{array}{l}\text { After } 3 \text { months } \\
\mathrm{N}=50\end{array}$} & \multirow[t]{2}{*}{$\chi^{2}$} & \multirow[t]{2}{*}{ P-value } \\
\hline & Freq. & $\%$ & Freq & $\%$ & Freq & $\%$ & & \\
\hline $\begin{array}{l}\text { Provider prepares delivery pack and other essential } \\
\text { materials according to National Guidelines. }\end{array}$ & 49 & 98.0 & 50 & 100 & 50 & 100 & 2.013 & $\begin{array}{l}.365 \\
\mathrm{NS}\end{array}$ \\
\hline $\begin{array}{l}\text { Allows the woman to give birth in the position she } \\
\text { wants and in the same bed where she has labored } \\
\text { (if possible) }\end{array}$ & 50 & 100 & 50 & 100 & 50 & 100 & $\cdots \cdots$ & $\ldots \ldots$ \\
\hline Ensures privacy of the woman. & 0 & .0 & 50 & 100 & 27 & 54.0 & 100.285 & $.000 *$ \\
\hline $\begin{array}{l}\text { Explains to the woman how to help herself and } \\
\text { manage the bearing down process (when and how) }\end{array}$ & 50 & 100 & 50 & 100 & 50 & 100 & & \\
\hline $\begin{array}{l}\text { Encourages and speaks kindly to the woman } \\
\text { during labor }\end{array}$ & 0 & .0 & 50 & 100 & 27 & 54.0 & 100.285 & $.000 *$ \\
\hline $\begin{array}{l}\text { Encourages the woman to ask questions and } \\
\text { responds in easy-to-understand language }\end{array}$ & 0 & .0 & 50 & 100 & 27 & 54.0 & 100.285 & $.000 *$ \\
\hline Makes sure the woman's bladder is empty & 50 & 100 & 50 & 100 & 50 & 100 & ... & $\ldots$ \\
\hline Makes sure the woman is clean & 50 & 100 & 50 & 100 & 50 & 100 & ..... & $\ldots$ \\
\hline Registers procedures in clinical record & 50 & 100 & 50 & 100 & 50 & 100 & $\cdots$ & $\cdots \cdots$ \\
\hline
\end{tabular}

$\mathrm{NS}=$ No Significant difference $\quad *$ Statistically significant difference

Table (7) shows that, there were no statistically significant differences in nurses performance score regarding NLD-14 standard (The provider prepares to assist the delivery/ birth.) regards this criteria (Provider prepares delivery pack and other essential materials according to National Guidelines, Allows the woman to give birth in the position she wants and in the same bed where she has labored (if possible), Explains to the woman how to help herself and manage the bearing down process (when and how), Makes sure the woman is clean and Registers procedures in clinical record ), at base line assessment ( $p>0.05)$.

Table (8) Distribution of Nurses performance regarding NLD-17 standard

\begin{tabular}{|c|c|c|c|c|c|c|c|c|}
\hline \multirow{2}{*}{$\begin{array}{l}\text { NLD-17 } \\
\text { The provider properly monitors the newborn and } \\
\text { provides essential initial newborn care, and } \\
\text { subsequent care. }\end{array}$} & \multicolumn{2}{|c|}{$\begin{array}{l}\text { Pre } \\
\mathrm{N}=50\end{array}$} & \multicolumn{2}{|c|}{$\begin{array}{l}\text { Immediate } \\
\mathrm{N}=50\end{array}$} & \multicolumn{2}{|c|}{$\begin{array}{l}\text { After 3months } \\
\mathrm{N}=50\end{array}$} & \multirow[t]{2}{*}{$\chi^{2}$} & \multirow[t]{2}{*}{ P-value } \\
\hline & Freq & $\%$ & Freq. & $\%$ & Freq. & $\%$ & & \\
\hline $\begin{array}{l}\text { Keeps the woman and her newborn together and } \\
\text { never leaves them alone }\end{array}$ & 0 & .0 & 50 & 100 & 50 & 100.0 & 150.00 & $.000^{*}$ \\
\hline $\begin{array}{l}\text { Ensures that the baby is well covered, is with the } \\
\text { mother and has began to suckle within one hour of } \\
\text { birth }\end{array}$ & 0 & .0 & 49 & 98.0 & 49 & 98.0 & 141.346 & $.000^{*}$ \\
\hline Provides routine essential care of the newborn. & 0 & .0 & 49 & 98.0 & 49 & 98.0 & 141.346 & $.000 *$ \\
\hline Ensures Baby is warm at all times. & 0 & .0 & 49 & 98.0 & 49 & 98.0 & 141.346 & $.000^{*}$ \\
\hline $\begin{array}{l}\text { Monitors the baby closely during at least the first six } \\
\text { hours after birth (at the same time as the postpartum } \\
\text { woman is monitored) }\end{array}$ & 0 & .0 & 50 & 100 & 50 & 100.0 & 150.00 & $.000 *$ \\
\hline $\begin{array}{l}\text { Monitors and records passage of meconium and } \\
\text { urine }\end{array}$ & 0 & .0 & 49 & 98.0 & 49 & 98.0 & 141.346 & $.000 *$ \\
\hline Informs parents of findings & 0 & .0 & 49 & 98.0 & 49 & 98.0 & 141.346 & $.000 *$ \\
\hline $\begin{array}{l}\text { Gives the baby the appropriate immunizations and } \\
\text { issues the appropriate under-five card }\end{array}$ & 0 & .0 & 0 & .0 & 0 & .0 & $\cdots$ & $\ldots$. \\
\hline
\end{tabular}


Table (8) shows that, there were no statistically significant differences in nurses performance score regarding NLD-17 standard (The provider properly monitors the newborn and provides essential initial newborn care, and subsequent care) regarding this criteria (Gives the baby the appropriate immunizations and issues the appropriate under- five card), at base line assessment ( $p>0.05)$. While the difference observed was highly statistically significant improvement in total performance score of nurses immediately and after three months of intervention compared with base line total score $(\mathrm{P}<$ $0.001)$

Table (9) Distribution of Nurses' performance regarding NLD-18 standard

\begin{tabular}{|c|c|c|c|c|c|c|c|c|}
\hline \multirow{2}{*}{$\begin{array}{l}\text { NLD-18 } \\
\text { The provider properly disposes of the used } \\
\text { instruments and medical waste after assisting the } \\
\text { birth. }\end{array}$} & \multicolumn{2}{|l|}{$\begin{array}{l}\text { Pre } \\
\mathrm{N}=50\end{array}$} & \multicolumn{2}{|c|}{$\begin{array}{l}\text { Immediate } \\
\mathrm{N}=50\end{array}$} & \multicolumn{2}{|c|}{$\begin{array}{l}\text { After } 3 \text { months } \\
\mathrm{N}=50\end{array}$} & \multirow[t]{2}{*}{$\chi^{2}$} & \multirow[t]{2}{*}{ P-value } \\
\hline & Freq. & $\%$ & Freq. & $\%$ & Freq. & $\%$ & & \\
\hline $\begin{array}{l}\text { Puts on gloves while disposing of used } \\
\text { instruments and medical waste }\end{array}$ & 50 & 100 & 50 & 100 & 50 & 100 & $\ldots \ldots$ & $\ldots$ \\
\hline $\begin{array}{l}\text { Discards the placenta in a leak-proof container } \\
\text { with a plastic liner }\end{array}$ & 0 & .0 & 50 & 100.0 & 29 & 58.0 & 101.141 & $.000 *$ \\
\hline $\begin{array}{l}\text { Disposes of medical waste (gauze, etc.) in a } \\
\text { plastic container with a plastic liner. }\end{array}$ & 49 & 98.0 & 49 & 98.0 & 29 & 58.0 & 41.082 & $.000 *$ \\
\hline Puts the soiled linen in a leak-proof container & 49 & 98.0 & 49 & 98.0 & 50 & 100.0 & 1.014 & $\begin{array}{l}.602 \\
\mathrm{NS}\end{array}$ \\
\hline $\begin{array}{l}\text { Opens (un-hinges) all instruments and immerses } \\
\text { them in a } 0.5 \% \text { chlorine solution for } 10 \text { minutes }\end{array}$ & 0 & .0 & 50 & 100.0 & 29 & 58.0 & 101.141 & $.000^{*}$ \\
\hline $\begin{array}{l}\text { Disposes of all sharps and syringes per national } \\
\text { Infection Prevention guidelines. the sharps } \\
\text { container }\end{array}$ & 28 & 56.0 & 49 & 98.0 & 50 & 100.0 & 47.552 & $.000 *$ \\
\hline $\begin{array}{l}\text { Removes and disposes of gloves and Performs } \\
\text { hand hygiene after removing gloves according } \\
\text { to Infection Prevention guidelines }\end{array}$ & 28 & 56.0 & 49 & 98.0 & 50 & 100.0 & 47.552 & $.000^{*}$ \\
\hline
\end{tabular}

$\mathrm{NS}=$ No Significant difference $\quad *$ statistically significant difference

Table (9) explore that, there were highly statistically significant improvement in total performance score of nurses regarding NLD-18 standard (The provider properly disposes of the used instruments and medical waste after assisting the birth.) immediately and after three months of intervention compared to pretest $(\mathrm{P}<0.001)$. While there were no statistically significant differences in nurses performance score regarding (Puts the soiled linen in a leakproof container $\quad(\mathrm{P}>0.05)$

Table (10) mean scores of nurses performance regarding ( standard 1, standard 3, standard 6, standard 7, standard 13, standard 14, standard 17, standard 18, ( Pre, post and 3 months later after application of standards).

\begin{tabular}{|l|l|l|l|l|l|}
\hline \multirow{2}{*}{ Items } & Pretest & Immediate & After 3 months & F & \multirow{2}{*}{ P value } \\
\cline { 2 - 5 } & Mean \pm S.D & Mean \pm S.D & Mean \pm S.D & & \\
\hline Standard 1 & $9.8 \pm .6$ & $12.0 \pm .0$ & $10.6 \pm .5$ & 323.1 & $.000^{*}$ \\
\hline Standard 3 & $12.2 \pm .4$ & $15.0 \pm .0$ & $15.0 \pm .0$ & 246.4 & $.000^{*}$ \\
\hline Standard 6 & $11.4 \pm 1.7$ & $14.8 \pm 3.9$ & $13.8 \pm 3.4$ & 15.8 & $.000^{*}$ \\
\hline Standard 7 & $13.7 \pm 1.9$ & $20.9 \pm .1$ & $14.4 \pm 4.8$ & 89.9 & $.000^{*}$ \\
\hline Standard 11 & \pm .0 & $18.0 \pm .0$ & $17.9 \pm .1$ & 202.0 & $.000^{*}$ \\
\hline Standard 13 & $16.0 \pm .0$ & $32.0 \pm .0$ & $20.5 \pm 7.3$ & 194.1 & $.000^{*}$ \\
\hline Standard 14 & $13.9 \pm .1$ & $18.0 \pm .0$ & $15.6 \pm 1.5$ & 266.4 & $.000^{*}$ \\
\hline Standard 17 & $10.0 \pm .0$ & $18.8 \pm 1.1$ & $18.3 \pm 1.8$ & 140.1 & $.000^{*}$ \\
\hline Standard 18 & $11.1 \pm 1.0$ & $13.9 \pm .6$ & $12.7 \pm 1.5$ & 85.5 & $.000^{*}$ \\
\hline Total performance level & $107.1 \pm 3.1$ & $163.5 \pm 8.2$ & $138.9 \pm 11.5$ & 761.8 & $.000^{*}$ \\
\hline
\end{tabular}

Table (10) shows the mean scores of nurses' $s$ performance regarding ( standard 1 , standard 3, standard 6, standard 7, standard 11, standard 13, standard 14, standard 17, standard 18, standard 7, and total performance level ) ( Pre, post and 3 months later after application of standards). $\mathrm{P}$ a g e $\mid \mathbf{3 0}$
The significant difference were found concerning, immediately and after 3 months and total scores of nurses' performance were highly statistical significant difference was illustrated $(\mathrm{p}<0.001)$, while the mean scores of nurses' performance $(163.5 \pm 8.2)$ immediate post test was the higher Naglaa F., et al 


\section{Discussion}

The risks of adverse outcome to the mother and baby are usually highest during the intrapartum period. Even though health experts have long appreciated this fact, prioritization of this element of safe motherhood is comparatively recent. The aim of applying standards in normal birth is to achieve a healthy mother and fetus with least possible level of interventions that is compatible with the safety [9]

Research Hypothesis of this study, There was a positive effect of Applying Standards for nursing care to improve the quality of nursing performance at labor unit? the researcher conducted this study for applying Standards for nursing care to improve the quality of nursing performance at labor unit.

The present study showed that, NLD-01 standard which was related to "The provider in charge prepares equipment, supplies and the environment to conduct clean and safe deliveries" there were no statistically significant differences in nurses performance score regarding only, nearly half of the criteria among all studied hospitals. The current study were in agreement with the results of (Kongnyuy and Van Den Broek 2013) . But they were in contrast with studies done by (Penfold et al 2013) who reported inadequate equipments, drugs and supplies for maternity and neonatal care [10]

As regards to, NLD-03 standard which is related to "The provider treats the pregnant woman in labor in a cordial manner" there was highly statistically significant improvement in total performance score of nurses only, three criteria were achieved among all studied hospitals. The current study was in agreement with the results of Kongnyuy and Van Den Broek 2013 who established local standards for women's friendly care, which emphasized that the outcome criteria must be at least $80 \%$ of women be satisfied with the reception they received at the labor ward .In the same standard, there were no significant differences among all studied hospitals for criteria no. 1, $2,5,6,8$.

This may be due to the insurance cover from their organization, but the rest of studied hospitals have emergency admissions which was characterized by caseload all over the hot days, so they neglect greeting the women, this is supported by Samia et al (2012) who found the same results, and who also reported that health care providers and hospital policy were not happy to allow companion in labor.

The findings of the present study were in disagreement with the findings of Olayinka et al., 2013 who found that the midwives attitude towards women in labor was $77.5 \%$ women were warmly received by midwives during labor and $68.75 \%$ said they were given information about their labor on admission. [11]

Regarding, NLD-06 standard which is related to "The provider properly conducts the obstetric examination between contractions if time allows", for criteria no. 2,3,5,9 were not achieved among all studied hospitals pre implementation of the study. Also there were highly statistically significant improvement in total performance score of nurses regarding (Pre, post and 3 months later after application of standards) ( $\mathrm{p}<0.001)$. These findings contradict with Kagema et al., 2014 who reported that during the initial assessment of woman in labor, the health

P a g e | 31 workers checked fundal height, presentation, and lie were $(99 \%)$ in Kenya facilities [12]

From the view of researcher it was reported that, using abdominal ultrasound is more accurate for determining the gestational age than measuring of fundal height (criterion no. 3), also health care providers depended on performance of vaginal examination to determine the onset of labor instead of abdominal palpation (criterion no. 4).

Regarding NLD-07 standard which is related to "The provider properly conducts a vaginal examination" There were statistically significant improvement in total performance score of nurses, immediately post implementation and some dropped in follow-up phases (after three months of intervention) compared with pre-test total score $(\mathrm{P}<0.001)$. The drop of nurses' performance was due to being not allowed, for the nurses to perform vaginal examination in study hospitals but allowed for physician only and the large number of internship physician. (Ahmed AAM ,2015).An Other study conducted by Muliira et al (2013) found that midwives were not careful about vaginal examination.[13]

Surprisingly, criterion no. 2,3,5,9,10,11 which related to performs hand hygiene, put on sterile gloves, cleans the vulva, explains the finding to the woman and registers finding were not achieved among all hospitals pre implementation of the standard, the result of the current was against WHO 2015 infection control protocols that reported recommended guidelines about the universal precautions in health care is the primary measure effective in preventing health care associated infection (HCAI) [14]

The partograph provides a graphical illustration of the progress of labor and is considered a valuable tool for managing women. Concerning, NLD-13 standard which is related to "The provider uses the partograph to monitor labor and make adjustments to care when necessary", the current study findings showed that the partograph is underutilized among studied hospitals before implementation of the standard. but There were statistically significant improvement in total performance score of nurses, immediately post implementation and some dropped in follow-up phases (after three months of intervention) $(\mathrm{P}<$ 0.001). The current study finding was in accordance with the results of the study conducted by RANIA EL-KURDY, M.Sc (2014) who found that the partograph is underutilized among the four studied hospitals and it is still not applied.

Staff shortages, busy departments and limited resources were also listed as reasons for non-usage of the partograph. Researchers from other studies also indicated that busy departments, staff shortage and limited resources played a huge role in the under-utilization of the partograph (Opiah et al. 2014) whilst Fatusi et al. (2016) stated, lack of time' as a reason for not completing partograph [15] [16].

Regarding NLD-14 standard which is related to "The provider prepares to assist the delivery/ birth", the current study findings illustrated that for criteria no. 3, 5, 6, they were not achieved among all studied hospitals before implementation of the study. These results were disagreement with the results of Kongnyuy and Van Den Broek 2013 who established local standards for women is friendly care which emphasized on the outcome criteria to 
be at least $80 \%$ of women who are satisfied with the reception they received at the labor ward. [10]

As regards to NLD-17 standard which is related to "The provider properly monitors the newborn and provides essential initial newborn care, and subsequent care.", the current study findings revealed that there were highly significant differences in improvement in the total performance score of nurses immediately and after three months of applying standard. This is consistent with the Military Obstetrics and Gynaecology, 2014; which indicated that newborns, during the first few hours of life, have some difficulty maintaining their body heat and may develop hypothermia if not attended to carefully.

As regards NLD-18 standard which is related to "The provider properly disposes of the used instruments and medical waste after assisting the birth..", the current study findings revealed that there were highly significant differences in improvement in total performance score of nurses immediately and after three months of applying $(\mathrm{P}<$ 0.001).while the current study findings illustrated that the criteria no. 2 and 5, were not achieved among all studied hospitals before implementation of the study.

The current study finding was in agreement with the study conducted by Friday et al (2012) who found that the sterilization practices varied widely among facilities and this difference was due to the nature pattern of existing policies relating to sterilization practices in labor units . This result was against WHO 2016 infection control protocols that reported recommended guidelines about discarding the medical waste in health care as the primary measure effective in preventing health care associated infection (HCAI) .[17].

The current study emphasized and supported the hypothesis for applying Performance Standards for Maternal and Neonatal Health (NORMAL LABOR AND DELIVERY)which seems to be very important and effective in improving the quality of nursing performance at labor unit.

\section{Conclusion}

In the light of the present study results, it could be concluded that, the present study showed low percentage of achievement regarding some performance standards for maternal and neonatal health (NLD) among all studied hospitals before intervention. It was clear that there was improvement in achievements of performance standards for Normal Labor and Delivery (NLD) after application of this study immediately better than three months later follow

\section{Recommendations}

Based on finding of this study. The following are recommended

- Continuing education unit in the hospital should schedule for training course for neonatal and obstetric nurses.

- Ensures availability of supplies and equipment to manage the normal newborn and maternal care .

- Continuous quality control by nursing manager to ensure high quality of care and positive attitude towards women in labor.
- Protect women from any physical and psychological harm during labor and child bear

- Develop evidence-based maternity \& neonatal care manual in all hospital based on established evidence-based practice with national standards.

- Further researches according to (WHO) recommendations to improve breastfeeding counseling.

\section{References}

[1]. World Health Organization (WHO) (2014): Mother Baby Package: Implementing Safe-Motherhood in Countries, Geneva, , P.P.44-49.

[2]. World Health Organization (WHO) (2009): Standards of Midwifery Practice for Safe Motherhood, , volume 1(2), P.iii.

[3]. Decherney, A. and Nathan, L.( 2013): Current Obstetrics and Gynecologic, 9th Edition, NewYork, Mc Gram-Hill companies, , P 213.

[4]. Philipsen, N. and MuMullen, P.: Fetal Wellbeing I (2014): The Health Care Provider's Responsibility in the First Trimester. Nursing Connections, a, 7(2),P.P.32- 33.

[5]. De Brouwere, V. and W. Van Lerberghe, W.( 2011,): Safe Mother Hood Strategies: A Review of the Evidence, Vol. 17, P.512.

[6]. KVIST L., DAMIATI N., ROSENQVIST J., et al.( 2011.): Measuring the quality of documented care given by Swedish midwives during birth. Midwifery, 27 (6): 188-94,

[7]. College of Registered Nurses of Nova Scotia. (2011). Professional practice issues resolution framework. Halifax: Author.

[8]. College of Registered Nurses of Nova Scotia. (2012). Nurse Practitioner Standards of Practice. Halifax: Author.

[9]. World Health Organization., (2012): Media centre, Maternal mortality; Fact sheet $N^{\circ} 348$; Key facts. Retrieved from http:// www.who.int/mediacentre/factsheets/fs348/en/inde x.html,.

[10]. Kongnyuy E. and Van Den Broek N.( 2013): Criteria for clinical audit of women friendly care and providers' perception in Malawi. BMC Pregnancy and Childbirth, 8 (28): 1-9, Retrieved from http://www.biomedcentral.com/content/pdf/1471-2393-8-28.pdf.

[11]. Olayinka O., Mombel O., Achi O. and Azibaben I.(2013): Perceived effects of midwives attitude towards women in labour in Bayelsa State, Nigeria. Archives of Applied Science Research, 4 (2): 960964, .

[12]. Kagema F., Ricca J., Rawlins B., Rosen H., Lynamp.( 2014) : and KIDULA N.: Quality of care for prevention and management of common 
maternal and newborn complications: Findings from a National Health Facility Survey in Kenya. Are services provided according to international standards? United States Agency for Inter-national Development's (USAID). Maternal and Child Health Integrated Program (MCHIP) Retrieved from http://www.mchip.net/node/455.

[13]. Muliira et al, (2013): Improving vaginal examinations performed by midwife, is an essential part of midwifery care, and is routinely performed when assessing the progress of labor. As evidence shows that during labor women may find VEs ...

[14]. World Health Organization, (2015): Who guidelines on hand hygiene in health care. First global patient safety challenge. Clean care is safer care. World Health Organization, patient safety. Geneva. Retrieved from http://whqlibdoc. who.int/publications/2009/9789241597906_eng.pd.

[15]. Opiah M., Ofi A., Essien E., et al. (2014): Knowledge and Utilization of the Partograph among Midwives in the Niger Delta Region of Nigeria. African Journal of Reproductive Health, 16 (1): 125-132,.

[16]. Fistula Care and the Maternal Health Task Force, (2016): Revitalizing the partograph: Does the evidence support A global call to action? Report of an Expert Meeting, Desmond Tutu Center New York, NY 10011 USA. Retrieved from htttp://www. fistulacare.org/pages/pdf/programrepor ts /EngenderHealth-Fistula-Care-PartographMeeting-Report-9-April-12.pdf.

[17]. World Health Organization, (2015): Who guidelines on hand hygiene in health care. First global patient safety challenge. Clean care is safer care. World Health Organization, patient safety. Geneva. Retrieved from http://whqlibdoc. who.int/publications/2009/9789241597906_eng.pdf 